\title{
WOYZECK E O BRASIL: TRILHANDO SUA RECEPÇÃO
}

Igor de Almeida Silva ${ }^{1}$

Resumo: Este trabalho apresenta um estudo introdutório sobre a recepção brasileira à obra teatral inacabada Woyzeck do dramaturgo alemão Georg Büchner, almejando obter um painel histórico das diferentes leituras desta peça no Brasil, a partir de algumas de suas encenações e dos ensaios produzidos por críticos e germanistas.

Palavras-chave: Dramaturgia alemã, Estética da recepção, Teatro brasileiro.

Abstract: This work is an introductory study on the Brazilian reception of the unfinished theatrical work Woyzeck by the German playwright Georg Büchner, hoping to provide a historical picture of the different readings of this play in Brazil on the basis of some of its stagings and of essays produced by critics and Germanists.

Key words: German drama, Aesthetic of reception, Brazilian theater.

\section{I}

O dramaturgo alemão Georg Büchner (1813-1837) é considerado um dos gênios precoces da história do teatro. Escreveu o drama $A$ morte de Danton (1835), uma desencantada visão sobre a Revolução Francesa e o herói revolucionário; Leonce e Lena (1836), comédia do tédio e do niilismo, trata com humor e pessimismo a humanidade e suas instituições de poder; o fragmento dramático Woyzeck (1836) que mostra o processo de aniquilamento de um passivo soldado diante de um mundo opressor; o panfleto revolucionário O mensageiro rural de Hesse (1834) em que expunha sua visão política, sendo, por isso, "considerado precursor de um socialismo muito anterior às teorias marxistas" (ARON, 1993, p. 35), e a novela Lenz. (1835) que trata da insanidade que se abateu sobre o poeta e dramaturgo alemão J. M. R. Lenz (1751-1792).

Dentre as obras citadas, neste artigo, debruçar-nos-emos, especificamente, na recepção brasileira da obra seminal de Büchner, Woyzeck, partindo de sua primeira encenação, em 1948, pelas mãos do encenador polonês, radicado no Brasil, Ziembinski, passando pelos diversos estudos acadêmicos e ensaios dedicados à peça em questão, produzidos por Erwin Theodor Rosenthal, Sábato Magaldi, Anatol Rosenfeld, Irene Aron e Fernando Peixoto até chegar à sua mais radical recriação em palcos brasileiros, realizada por Cibele Forjaz, Fernando Bonassi e Matheus Nachtergaele, a partir da recepção dos críticos Fátima Saadi, Sérgio Coelho e Mari-

1 Mestre em Teoria Literária pelo Programa de Pós-Graduação em Letras e Lingüística, da Universidade Federal de Pernambuco - UFPE. Endereço eletrônico: ialmeidasilva @uol.com.br. 
ângela Alves de Lima. Almejamos, através deste estudo introdutório, mostrar a variedade de recepções de $W$ oyzeck no Brasil, concentrando-nos, sobretudo, na sua recepção ensaística e enfatizando sua capacidade de oferecer diferentes respostas a cada novo horizonte de expectativa.

\section{II}

A recepção brasileira de Woyzeck inicia-se em 1948, com a montagem de Ziembinski, para o Teatro Popular de Arte de Sandro Poloni e Maria Della Costa, sob o título de Lua de Sangue. Esta encenação, além de ter sido a primeira a ser realizada no Brasil, foi também a primeira montagem latino-americana de Woyzeck, recebendo inclusive, elogios do crítico Roberto Brandão (pseudônimo de Pompeu de Souza) no Diário Carioca: "O escritor pré-expressionista encontra na arte do diretor pós-expressionista uma consonância e uma ressonância extraordinária" (BRANDÃO, 1948 apud MICHALSKI, 1995, p. 134). No entanto, apesar de belo, o espetáculo saiu de cartaz do Teatro Fênix, no Rio de janeiro, onze dias após sua estréia. Houve um choque estético entre Woyzeck e o público brasileiro. O dramaturgo alemão e o encenador polonês não conseguiram transformar seu espectador real brasileiro no receptor implícito ou espectador ideal que havia sido desenhado pelo trabalho da escrita e da cena. Para José Sanchis Sinisterra, esse é o problema fundamental da dramaturgia e/ou da encenação: a "transmutação do espectador real no espectador ideal que construímos” (SINISTERRA, [1995] 2002, p. 70). E, no que concerne especificamente ao papel do dramaturgo, segundo Sinisterra, seu trabalho baseia-se "em desenhar esse espectador ideal ou receptor implícito para que o hipotético espectador real aceite transformar-se nesse desenho" (SINISTERRA, [1995] 2002, p. 73-74). No caso da recepção brasileira à montagem de Ziembinski, constatamos que o nosso horizonte de expectativa ainda se encontrava subserviente aos antigos modismos e ao gosto pelo risível e farsesco da comédia de costumes e do teatro musicado dos inícios do século XX. Por isso, nosso público não estava suficientemente preparado para absorver as inovações de $W o y$ zeck, rejeitando, dessa forma, o desenho proposto pela dramaturgia.

\section{III}

Mesmo após essa fria recepção, o interesse por Woyzeck e também pelo restante da obra de Büchner cresceram progressivamente no ensaísmo brasileiro. Em 1961, é publicado o livro O trágico na obra de Büchner, de Erwin Theodor Rosenthal, primeiro estudo acadêmico no Brasil sobre a obra do autor alemão, escrito originalmente como resultado de uma tese de livre-docência à cadeira de Língua e Literatura Alemã pela Faculdade de Filosofia, Ciências e Letras da Universidade de São Paulo. Neste estudo, Rosenthal ressalta a atualidade da obra büchneriana, as diversas possibilidades de interpretações e filiações a correntes estéticas que ela suscita. 
No entanto, ele não vê isso como algo positivo: o erro fundamental da crítica foi ter encaminhado suas análises de modo unilateral, apreendendo apenas um aspecto de sua obra. Para ele, o dramaturgo alemão tem "uma experiência muito mais ampla, e é muito menos simples em suas interpretações da existência" (ROSENTHAL, 1961, p. 33). Por isso, não é "possível afirmar que tenha sido realista, fascista, comunista, romântico, niilista ou rotulá-lo de qualquer outra maneira" (ROSENTHAL, 1961, p. 34). Portanto, o único adjetivo possível a Büchner seria o de revolucionário. Não no sentido político que tanto marcou sua vida, mas no sentido poético que determinou sua obra. A verdadeira revolução encontra-se não em seus temas, mas na sua linguagem.

Dessa forma, para se opor às interpretações marxistas, Rosenthal propõe-se a identificar a essência do teatro de Büchner na sua tragicidade. No entanto, essa análise não pretende descobrir aspectos da obra, obscurecidos pelas sucessivas recepções históricas, mas uma essência imanente e atemporal que enalteça o gênio do poeta e o legitime como um autor clássico. Ou seja, ao invés de admitir a multiplicidade de interpretações como um fator positivo, Rosenthal as rejeita e direciona sua análise também de maneira unilateral, semelhante aos críticos que acusava. Provavelmente, o ensaísta não compreendeu que o teatro de Büchner mantém-se vivo justamente pela diversidade de respostas que ele sugere às indagações de diferentes épocas, seja nos seus aspectos humanos, seja no que concerne a questões político-sociais; isso não é necessariamente uma falha do crítico, mas uma contingência histórica a que todos os leitores são susceptíveis, inclusive o próprio Rosenthal.

\section{IV}

Em 1963, quando do sesquicentenário de nascimento de Georg Büchner, foi publicada uma edição especial do Suplemento Literário de O Estado de S. Paulo com ensaios de Otto Maria Carpeaux, Anatol Rosenfeld, Sábato Magaldi e Mario da Silva entre outros. Dentre esses ensaios, destacamos o de Sábato Magaldi sobre Woyzeck, intitulado "Woyzeck, Büchner e a Condição Humana". Aqui, Magaldi detém-se em aspectos estilísticos do uso da linguagem, não se guiando de imediato ao seu conteúdo, mas percebendo primeiro sua forma, seus contornos. Admira seu estilo despretensioso, áspero e não polido, e ressalta a evolução estilística que se dá em Büchner desde sua primeira peça, $A$ morte de Danton, até $W$ oyzeck, onde, segundo ele, há maior precisão na linguagem. Compara-o a pilares da literatura do século XX como Kafka e Beckett. Em seguida, coloca Woyzeck em diálogo com Shakespeare, Brecht e o expressionismo:

Woyzeck compõe-se de vinte e cinco cenas, que não guardam unidade de lugar nem de tempo [...]. Cada flagrante tem unidade interna, e, a propósito dessa téc- 
nica, certamente sugerida pela liberdade shakespeariana, pode-se pensar em certos preceitos da teoria épica de Brecht: tensão desde o início, as cenas justificamse por si mesmas e os acontecimentos apresentam-se em curvas. A admirável arquitetura cênica se organiza, como em algumas obras de Brecht, pela justaposição de cenas aparentemente soltas. Os outros requisitos do Organon brechtiano, não observados ainda por Büchner, é que não conferem às suas peças o qualitativo de épicas.

$[\ldots]$

Büchner justapõe flagrantes e se dispensa dos longos intróitos preparatórios. Um diálogo é captado no clímax. O atrito das personagens surge no momento decisivo, fustigando permanentemente os nervos do espectador. Abole-se a censura, e os indivíduos falam muitas vezes como se dessem largas ao seu delírio subconsciente. Essa explosão de cada criatura faz do diálogo uma ponte de incomunicabilidade, em que todos cumprem sem remédio sua caminhada solitária. Teatralmente, pinta-se uma vertigem, que será um dos ideais do expressionismo (MAGALDI, [1963] 1989, p. 167-168).

A partir desta análise, percebemos um exemplo do processo de recepção e de evolução estética da obra de arte, sugerido por Hans Robert Jauss (1921-1997) no seu ensaio Literaturgeschichte als Provokation der Literaturwissenschaft ([1967] 1990), quando Magaldi põe Büchner como receptor da experiência estética shakespeariana no Renascimento Inglês e precursor do expressionismo alemão e das teorias do teatro épico brechtiano, surgidos no século XX. De acordo com a Estética da Recepção, o leitor ou o expectador não é um elemento passivo. Pelo contrário, sua ação possibilita a continuidade da experiência estética, onde as constantes transformações históricas permitem a passagem da recepção passiva à recepção ativa, da simples leitura à compreensão crítica da norma estética já estabelecida à sua renovação através do nascimento de uma outra. Ou seja, no caso de Büchner, para expressar as transições sociais e políticas de sua época, ele reatualizou uma forma dramática, originária dos autos medievais, forma da qual a dramaturgia shakespeariana também é descendente e diluidora, num processo de recepção, redirecionado por uma nova perspectiva e que surge como resposta a um novo horizonte de expectativa, imediatamente percebido por Büchner e que, por sua vez, preconiza e influencia a experiência estética futura: o expressionismo e o teatro épico.

Voltando a Magaldi, além da depuração da linguagem, há ainda uma outra evolução em Woyzeck: o "esclarecimento total da idéia de tragicidade" (MAGALDI, [1963] 2004, p. 334). Retoma as primeiras considerações lançadas por Rosenthal, indo, porém, mais além. Para Magaldi, mesmo que entre os trágicos gregos (Ésquilo, Sófocles e Eurípides) haja uma diversidade de imagens desse gênero, existe um denominador comum entre os três que seria a "relação do homem com a divindade, que ora o submete ao seu arbítrio, ora cede ao ímpeto humano de afirmar-se livre" (MAGALDI, [1963] 2004, p. 340). No entanto, a tragédia de 
Büchner, segundo o crítico, tem um sabor mais amargo, pois agora, o ser humano não se depara mais com a força imanente e determinante do divino, mas com sua ausência: "o despovoamento do céu levou o homem a deblaterar-se num mundo vazio, e o nada transformou-se no seu estigma fatal. Vem do vácuo o aniquilamento" (MAGALDI, [1963] 2004, p. 340).

V

Em 1965, o crítico e ensaísta Anatol Rosenfeld publica o livro O teatro épico, onde investiga a presença de traços épicos (que na época era uma questão bastante em voga devido às teorias de Bertolt Brecht) na dramaturgia e nas manifestações teatrais ocidentais e orientais, desde os gregos até os dramaturgos modernos do século XX, incluindo, dessa forma, Woyzeck e as demais obras de Büchner em seu estudo. Nesse ensaio, Rosenfeld extrai quatro aspectos que concernem tanto à estrutura quanto à temática das peças de Büchner. O primeiro deles, diz respeito à experiência do vazio. Segundo o ensaísta teuto-brasileiro, o sentimento de vazio e de tédio que atormenta os personagens de Büchner é fruto da própria experiência do autor diante da época em que viveu, cuja derrocada dos valores idealistas, em detrimento de uma concepção materialista do mundo e o fracasso dos seus impulsos revolucionários de socialista radical, suscitou no jovem Büchner uma sensação de vazio: "O mundo se lhe afigurava sem sentido, absurdo; o advento das novas concepções que pareciam despir o homem da sua liberdade e dignidade, encarando-o como joguete das forças históricas e de determinações naturais, somente poderia reforçar a visão niilista de Büchner" (ROSENFELD, [1965] 2004, p. 78).

Um segundo aspecto da obra de Büchner é a solidão dos seus personagens. Num mundo destituído de valor e sem sentido, a coletividade dá lugar a uma solidão coletiva. Esta solidão mostra-se não apenas num nível temático, mas também estrutural da obra, pois o efeito da solidão dilui o diálogo proporcionando inúmeros monólogos paralelos. O terceiro aspecto seria o absurdo e o tragicômico. Para o ensaísta, não é possível "conceber um herói [...] de quem se salienta o fato de não conseguir dominar o músculo constritor. Essa redução grotesca do clássico herói, imagem da dignidade humana, à sua pobre condição fisiológica é essencialmente tragicômica" (ROSENFELD, [1965] 2004, p. 80). Por último, o autor ressalta os traços épicos da dramaturgia büchneriana que, em Woyzecke, atingem seu esplendor, estabelecendo, portanto, diálogo com o já referido ensaio de Sábato Magaldi.

\section{VI}

Em 1983, Fernando Peixoto publica Georg Büchner: a dramaturgia do terror, sobre a vida e a obra do autor alemão. Neste livro introdutório, como reflexo de sua formação marxista e de sua experiência num "teatro engajado", Peixoto valoriza a importância histórica de $W$ oyzeck no contexto em que se deu sua fatura. Para ele, 
“independentemente da ênfase concedida à questão social ou psicológica, [Woyžeck] constitui o instante histórico em que o proletariado surge na qualidade de protagonista na dramaturgia universal". Enxerga no drama do soldado Woyzeck, não apenas a tragicidade de uma alma aniquilada por um mundo cruel que não consegue entender, mas também a problemática da luta de classes que tanto marcou a vida de Büchner, mesmo que, na época em que viveu, essa questão ainda não existisse nas mesmas proporções que adquiriu na contemporaneidade:

Büchner prossegue o estudo das relações de desespero e impotência entre o homem e o mundo, [...] transferindo-o para o terreno da luta de classes, transforma o povo em protagonista e materializa sua problemática, utilizando a aparente narrativa de um trágico crime passional [...] numa contundente denúncia de injustiça e do caráter desumano e opressor de um sistema social (PEIXOTO, 1983, p. 98).

\section{VII}

Após uma década, em 1993, a pesquisadora e ensaísta Irene Aron publica sua tese de doutorado Georg Büchner e a Modernidade, defendida em 1981, cujo orientador foi Erwin Theodor Rosenthal, onde analisa as peças $A$ morte de Danton e $W$ oyzeck a partir, sobretudo, de conceito de modernidade de Charles Baudelaire (18211867), utilizando-se também das teorias da Estética da Recepção para compreender a importância histórica de Büchner como precursor do teatro moderno, os fatores que impediram sua recepção na época em que viveu e a atualidade de sua obra.

No seu ensaio, Le peintre de la vie moderne (1863), Baudelaire defende como antítese da modernidade, "o belo eterno". Para ele, "la modernité, c'est le transitoire, le fugitif, le contingent, la moitié de l'art, dont l'autre moitié est l'éternel et l'immuable" (BAUDELAIRE, 1863). Por isso, o moderno, no sentido estético, não se distingue do passado ou do que é velho, mas do clássico: "[...] a consciência da modernidade vem à tona através da procura da inovação, aliada à ruptura de padrões estéticos tradicionais" (ARON, 1993, p. 30). Todavia, essa consciência apenas poderá ser atingida em detrimento da "capacidade crítica de percepção - expressa em forma e linguagem - de uma situação historicamente inusitada" (ARON, 1993, p. 30). Ou seja, "a modernidade como 'modo de percepção do histórico', é a capacidade de extrair da transitoriedade e da fugacidade de cada época aquilo que a caracteriza, ou seja, a sua marca, a sua essência" (ARON, 1993, p. 30). Todavia, para o autor de Les fleurs du mal, na modernidade, a busca pelo novo não se restringe à curiosidade em relação à novidade, porque o moderno guarda em si mesmo o eternamente belo de amanhã. É necessário extrair o eterno do transitório: “[...] pour que toute modernité soit digne de devenir antiquité, il faut que la beauté mystérieuse que la vie bumaine y met involontairement en ait été extraite" (BAUDELAIRE, 1863). 
Segundo Aron, o que determina a modernidade de Büchner é a forma e a linguagem que empregou para compor sua obra, atingindo a perfeição de seu estilo no fragmento dramático Woyzeck. Ela classifica a obra büchneriana como drama de forma aberta, cujas características são as mesmas que denominam o drama épico de Bertolt Brecht, variando apenas a nomenclatura ${ }^{2}$. O drama de forma aberta caracteriza-se pela falta de causalidade e linearidade entre as cenas, sincronia (duas ou mais ações ocorrendo paralelamente), ausência de unidades de tempo e espaço, o antagonista como o próprio mundo, independência e fragmentação das partes do drama, não havendo princípio, meio ou fim aparentes. A forma aberta apresenta-se como um fator de modernidade em Büchner pelo seu caráter inovador, ao se opor ao drama de forma fechada, ou seja, ao drama aristotélico, mas também e, sobretudo, por nascer de uma "profunda conexão com a realidade social que o cercava" (ARON, 1993, p. 54). As transições sociais e políticas de seu tempo refletem-se na sua obra pela sua organização formal, fragmentada, reflexo da ordem social no mundo.

Todavia, segundo Aron, geralmente, os modernos só atingem um público depois de seu momento histórico, assim como ocorreu com Büchner. Isto nos remete ao conceito do horizonte de expectativa, formulado por Jauss, onde as obras de vanguarda não são apreendidas pelo seu público original, ainda preso a padrões de gosto estético já estabelecidos e em vias de decadência. Seu valor só poderá chegar às gerações seguintes, quando a experiência anterior já tiver sido superada e o público estiver aberto à experiência futura. Segundo Aron, este seria o motivo pelo qual justifica-se o esquecimento de Büchner durante quase todo o século XIX. Dessa forma, tentando aproximar o conceito de modernidade de Baudelaire à Estética da Recepção de Jauss, a autora diz:

[...] a sobrevivência de obras do passado, consideradas eternas e perenemente válidas, é garantida por nossa consciência contemporânea de modernidade, que as abrange, revivifica e rejuvenesce. Ou seja, embora certas obras do passado sejam a expressão de sua época, nossa compreensão contemporânea do nosso tempo aproxima-nos delas, tornando-as precursoras da nossa modernidade (ARON, 1993, p. 31).

Finalmente, Aron conclui suas reflexões sobre a modernidade na obra de Büchner, afirmando que o modo crítico de percepção de seu tempo, expresso em forma e linguagem inovadoras, continua sendo moderno para nós, "porque a percepção contemporânea da modernidade estabelece a ponte entre a sua época e a nossa. Desta maneira, podemos dizer que Büchner continua falando ao nosso

2 Opinião divergente à de Sábato Magaldi que afirma que Woyzeck possui apenas algumas das características que vieram a configurar o drama épico, mas que, em sua totalidade, não pode ser confundido com esse gênero legitimado por Brecht. 
tempo, como se ainda estivesse entre nós" (ARON, 1993, p. 31). Por isso, ela acredita na modernidade de Büchner e, ao mesmo tempo, no valor perene de sua obra.

Confuso parece-nos o raciocínio de autora que aplica conjuntamente, na análise do teatro de Büchner, o conceito de modernidade de Baudelaire e a teoria da Estética da Recepção de Jauss. A primeira contradição é que, conceitualmente, ambas as teorias não se associam. Baudelaire trabalha com a idéia do eterno, do cânone, como se a modernidade fosse o clássico de amanhã. Esta tem seu valor eternizado por captar de maneira original a essência de uma época e que, por isso, seu valor será reconhecido pelas próximas gerações que a reconhecerão como precursora de sua própria modernidade. Dessa forma, uma obra nunca poderá ser moderna de fato, pois no momento em que ela é finalmente reconhecida como tal, já não será mais moderna, e sim clássica, uma vez que seu momento histórico já terá passado e apenas se reconhecerá seu papel de precursora da contemporaneidade. Em Baudelaire, o clássico e o moderno parecem ser faces de uma mesma moeda.

Essa concepção da arte é completamente contrária ao que Jauss propõe, porque sua teoria nega a existência dos valores eternos. A história literária baseada na estética da recepção tem como intenção buscar novos cânones artísticos, oporse ao neoclassicismo difundido pelo estudo da tradição, através do reexame crítico de cânones literários herdados do passado. $\mathrm{O}$ valor de um clássico não é eterno, pois uma obra do passado só é reconhecida quando as respostas que ela propicia, respondem às questões da contemporaneidade. Enquanto ela puder responder às interrogações de um tempo posterior e diferente do seu, terá seu valor e atualidade reconhecidos, mesmo que seu horizonte original já não mais exista. Seu esquecimento ocasiona-se justamente no momento em que ela cessa de responder às interpelações do presente. Não há, portanto, a partir da Estética da Recepção, o cânone eterno, porque a recepção é um permanente processo de reconhecimento, susceptível às contingências históricas e estéticas de cada época. Neste ensaio, Aron procura comprovar, através do conceito de modernidade, a atemporalidade de Büchner, seu valor como um "moderno extemporâneo", ou seja, um clássico. Trilha, portanto, caminho similar ao percorrido por seu orientador de tese, Erwin Theodor Rosenthal, ao tentar enquadrar Woyzeck dentro de uma visão neoclássica da arte (belo eterno, cânone atemporal, valor imanente), a que a própria Estética da Recepção se opõe.

\section{VIII}

No dia 15 de agosto de 2002, estréia Woyzeck, o Brasileiro, no Teatro Casa Grande, no Rio de Janeiro, criação da encenadora Cibele Forjaz, do escritor Fernando Bonassi e do ator Matheus Nachtergaele, que interpretou o papel-título. 
Nesta encenação que se propôs, segundo o crítico Sérgio Coelho, da Folha de S. Paulo, "como retrato do aqui e agora brasileiro" (COELHO, [2003] 2004, p. 371), Woyzeck é um brasileiro proletário "que adivinha a angústia da classe média, na qual não se inserirá nunca, mas de quem se faz porta voz" (COELHO, [2003] 2004, p. 372).

$\mathrm{Na}$ adaptação da peça, optou-se pela transposição de sua ação para uma olaria num ponto qualquer do Brasil, reorganizando-se suas cenas, atualizando a linguagem e substituindo "os ritos de convivência do proletariado alemão do século XIX" por "referências ao imaginário da cultura popular brasileira," (LIMA, [2003] 2004, p. 374). Liberdades que, entretanto, seguiam de perto o texto original na tentativa de preencher seus vazios, decorrentes da própria natureza da peça. Dessa forma, para completar suas lacunas, "os atores passaram a improvisar sobre o que esses fragmentos poderiam vir a ser. Mais do que apresentar a peça, era preciso terminá-la”, declara Fernando Bonassi (apud TRINDADE, 2002, p. 122). O autor selecionou as improvisações mais adequadas ao texto e criou o esqueleto dramatúrgico do espetáculo. Para Cibele Forjaz, seu Woyz̧eck é brasileiro, mesmo que não haja um lugar específico identificado pela encenação. Por isso, "a peça se passa dentro de uma olaria, que pode ser em qualquer lugar. Mas há uma brasilidade no próprio elenco, formado por gente de todo o país. É um microcosmo do Brasil. E ele também é brasileiro, porque é difícil não falar do aqui e agora quando se monta uma peça como esta" (apud TRINDADE, 2002, p. 122).

Para a crítica Fátima Saadi, o que chama a atenção neste procedimento é que, por um lado, acrescenta "mais uma camada ao verdadeiro palimpsesto que é o Woyzeck" e, por outro, nele instila "preocupações sociais e cênicas da nossa contemporaneidade" (SAADI, [2003] 2004, p. 370). Mariângela Alves de Lima, do Estado de S. Paulo, em crítica ao espetáculo, acrescenta ainda que o pragmatismo da encenação universaliza a classe trabalhadora e, mais do que isso, evidencia "uma interpretação do texto a um só tempo mítica e histórica” (LIMA, [2003] 2004, p. 374).

\section{IX}

Através dos ensaios e das encenações de Woyzeck, traçamos um breve panorama de sua recepção no Brasil, evidenciando sua multiplicidade de interpretações. Sua trajetória na cena e no pensamento teatral brasileiro começa com a encenação expressionista de Ziembinski, rejeitada pelo seu público original, passando pela sua apreciação nos ensaios de Erwin Theodor Rosenthal, Sábato Magaldi e Anatol Rosenfeld, durante a década de 1960, em que os respectivos ensaístas ressaltaram os aspectos formais e estilísticos da obra em questão, sem desconsiderar os aspectos metafísicos e existenciais de sua visão sobre a condição humana. No começo dos anos oitenta, Woyzeck é submetido ao olhar de Fernando Peixoto que, na sua 
recepção, destaca as questões políticas e históricas que subjazem na obra. Além disso, em nosso percurso, deparamos-nos com a busca pela modernidade de Büchner e de seu Woyzeck, através do estudo de Irene Aron. Finalmente, a recepção de Cibele Forjaz, Fernando Bonassi e Mateus Nachtergaele, cuja recriação do texto propõe uma aproximação imediata e radical do universo büchneriano à realidade brasileira, sendo considerado pelos críticos aos quais tivemos acesso uma bem sucedida e, ao mesmo tempo, "transtornante" experiência nos palcos brasileiros. Os criadores do espetáculo realizaram o que Anne Ubersfeld sugere para a encenação dos clássicos: "mostrar a recorrência da mesma situação de fala, outrora e hoje, privilegiar a diferença ou tentar uma relação: vai-e-vem, síntese dialética, conciliação eclética" (UBERSFELD, [1978] 2002, p. 20). Porque "ler hoje é des-ler o que foi lido ontem" (UBERSFELD, [1978] 2002, p. 12), é extrair dessa des-leitura o diálogo com o que se tem em comum, "a respeito do que concordar ou brigar, verdades sobre as quais fez-se um acordo tácito” (UBERSFELD, [1978] 2002, p. 18). Como diz Bonassi, "Büchner teve o cuidado ou o achado de escrever esta história manipulável” (apud TRINDADE, 2002, p. 122), por isso, a cada novo horizonte de expectativa seu Woyzeck respondeu, de diferentes maneiras, aos questionamentos do presente, do instante, fugaz e transitório. Histórico.

\section{REFERÊNCIAS}

ARON, Irene. Georg Büchner e a modernidade. São Paulo: Annablume, 1993.

BAUDELAIRE, Charles. [1863]. Le peintre de la vie moderne. Disponível em: http://www.uni-duisburg-essen.de/lyriktheorie/texte/1863_baudelaire.html. Acesso em: 01 mar. 2007.

BRANDÃO, Roberto. Ainda a rua e o bonde e etc. Diário Carioca, Rio de Janeiro, 11 jul. 1948. Apud: MICHALSKI, Yan. 1948: um ano de frenético trabalho. In: Ziembinski e o teatro brasileiro. São Paulo; Rio de Janeiro: Hucitec; Ministério da Cultura; Funarte, 1995.

BÜCHNER, Georg. [1836]. Woyzeck. In: GUINSBURG, J.; KOUDELA, Ingrid D. (Org., trad. e notas). Büchner: na pena e na cena. São Paulo: Perspectiva, 2004, p. 235-263.

COELHO, Sérgio. [2003] Experiência transtornante. In: GUINSBURG, J.; KOUDELA, Ingrid D. (Org., trad. e notas). Büchner: na pena e na cena. São Paulo: Perspectiva, 2004, p. 371-372.

GUINSBURG, J.; KOUDELA, Ingrid D. (Org., trad. e notas). Büchner: na pena e na cena. São Paulo: Perspectiva, 2004.

JAUSS, Hans Robert. [1967]. L'histoire de la littérature: un défi à la théorie littéraire. In: Id. Pour une esthétique de la réception. Trad. Claude Maillard. Paris: Gallimard, 1990, p. 23-88.

LIMA, Mariângela Alves de. [2003]. Woyzeck, em adaptação inteligente e sensível. In: GUINSBURG, J.; KOUDELA, Ingrid D. (Org., trad. e notas). Büchner: na pena e na cena. São Paulo: Perspectiva, 2004, p. 373-375.

MAGALDI, Sábato. [1963]. Woyzeck, Büchner e a condição humana. In: Id. O texto no teatro. São Paulo: Perspectiva, 1989, p.163-169. 
MICHALSKI, Yan. 1948: um ano de frenético trabalho. In: Ziembinski e o teatro brasileiro. São Paulo; Rio de Janeiro: Hucitec; Ministério da Cultura; Funarte, 1995.

PEIXOTO, Fernando. Georg Büchner: a dramaturgia do terror. São Paulo Brasiliense, 1983.

ROSENFELD, Anatol. [1965]. Georg Büchner. In: Id. O teatro épico. 4. ed. São Paulo: Perspectiva, 1985, cap. 8, p. 77-81.

ROSENTHAL, Erwin Theodor. O trágico na obra de Georg Büchner. São Paulo: Faculdade de Filosofia Ciências e Letras de Assis, 1961.

SAADI, Fátima. [2003]. A fricção do real. In: GUINSBURG, J.; KOUDELA, Ingrid D. (Org., trad. e notas). Büchner: na pena e na cena. São Paulo: Perspectiva, 2004, p. 369-370.

SINISTERRA, José Sanchis. [1995] Dramaturgia da recepção. Trad. Aline Casagrande. Folhetim, Rio de Janeiro, Teatro do Pequeno Gesto, n. 13, p. 66-79, abr./jun. 2002.

TRINDADE, Mauro. O fragmento brasileiro de Büchner. Bravo!, São Paulo, D’Avila, ano 5, n. 59, p. 118-122, ago. 2002.

UBERSFELD, Anne. [1978]. A representação dos clássicos: reescritura ou museu. Trad. Fátima Saadi. Folhetim, Rio de Janeiro, Teatro do Pequeno Gesto, n. 13, p. 8-37, abr./jun. 2002. 
